\title{
Book and Image in Byzantine Christianity: \\ Polemics or Communication?
}

\section{Introduction}

At least in some sense, the prevailing of an image culture in Byzantine Christianity can be said to reflect a theological choice in favour of Neoplatonic theurgy over and against a spiritualized, predominantly philosophical, religiosity -where 'theurgy' is intended to comprise the whole gamut of material trappings and rituals through which the relationship between the worldly and the divine sphere is established and cultivated. While icons, relics and liturgical instruments provide the main point of reference for this theurgic mediation, presenting specific issues appropriate to each and dominating the debates regarding the legitimacy of iconography, illustrations in books are not often discussed in this context. In this paper, I would like to argue that book illumination has at least an equally important role in supporting a case for the continued existence and use of iconography in Christianity. ${ }^{1}$ For, beginning with venerable biblical pandects such as the codex Sinaiticus and the codex Vaticanus, ${ }^{2}$ Greek manuscripts could have been the un-iconic 'icon' of Christianity par excellence. On the contrary, images crept into sacred books at an early stage, and there remained, and flourished, and grew, reaching a climax of sophistication and intensity in the Middle Byzantine Period. Why did the Christian book go so forcefully, so forthrightly, so thoroughly towards being an illustrated book? What ideas about imagery, and more

\footnotetext{
${ }^{1}$ I would like here to thank the organizers of the 'Byzantine Aesthetics and Theurgy' Round Table at the XXII International Byzantine Congress at Sofia, August 2011, for having accepted my paper and guided the session and ensuing discussion most efficiently and productively.

${ }^{2}$ M. Hengel, The Septuagint as Christian Scripture. Its Prehistory and the Problem of its Canon. Edinburgh and New York: T\&T Clark, 2002, with all essential bibliographical resources. For the Sinaiticus, cf. the webbased edition http://www.british-library.uk/onlinegallery/sacredtexts/codexsinai.html.
} 
specifically about the function of imagery in books, based in turn upon the function of sacred books, stimulated and supported the multiplication of art in them?

In an innovative and provocative article on the beginnings of biblical illustration, John Lowden remarks that "Christianity was established and developed as a religion of the book, or rather of many books. But by the early seventh century it had been transformed to a remarkable extent into a religion of the image, or rather many images." ${ }^{3}$ Lowden supports a view that has gathered momentum in the postWeitzmann era, namely, that we have no reason to extrapolate a much wider circulation of early Christian illustrated books from the scanty extant evidence. ${ }^{4}$ Lowden's enquiry consists in asking why imagery got into books in the first place, which is not our primary concern here, though of course one could re-examine that arguably more basic and more important question in view of the issues raised by later developments. According to Lowden, a process of natural osmosis between the images that appeared in monumental art, and that had become 'familiar' to the Christian believer, and the images found in books occurred, so that the latter were introduced into books as already part of the religious experience of the faithful, who were also the 'audience' for the book (or the book commissioners/buyers, perhaps). Lowden's proposal is in direct opposition to Weitzmann's suggestion that religious art developed in manuscripts and was then placed in more public spaces. Both approaches seek, from an art-historical point of view, to explain the direction in which iconography travelled between media, taking at times considerable leaps from the extant evidence, rather

\footnotetext{
${ }^{3}$ JoHn LOWDEN, The Beginnings of Biblical Illustration. In JoHn WiLLIAMs, editor, Imaging the Early Medieval Bible. University Park, PA, 1999, 10-59, at p. 10.

${ }^{4}$ For an appreciation of the epoch-making work of Kurt Weitzmann, see M. BERNABÒ, Una rivoluzione nello studio della miniatura medievale: Kurt Weitzmann e Illustrations in Roll and Codex. H. KessLER, Il contributo di Kurt Weitzmann alla storia della miniatura medievale. Miniatura, 3-4 1990-1, 109-12 and 113-16 respectively.
} 
than looking for the theoretical presuppositions that led to the development of imagery in books.

The comparable scarcity of illustrated manuscripts in the West, where fewer losses of early evidence are in general appreciable, strengthens Lowden's viewpoint. In the Latin world too, iconography in books is rare in the early period but increases exponentially from around the ninth/tenth century onwards, reaching a climax in the twelfth and thirteenth centuries with the production of the bibles moralizées. ${ }^{5}$ The extraordinary increase in and development of illustrated books in the Middle Byzantine period must therefore be taken at face value and evaluated on its own terms. Besides socioeconomic factors that determined the extremely high quality of the illustrations in manuscript productions of the eleventh and twelfth century, undoubtedly linked to questions of patronage, what interests us here is to enucleate a theoretical underpinning to such an intensified work of elaboration of illustrative cycles, bringing out elements that ground the aesthetic appeal of these creations into a wider ideological framework. Contrasting the aniconic devices that made the ancient Bible codices both dignified and legible -including a specific calligraphic script, the Biblical Majuscule, ornamental dividers and 'Figurengedichte', high-quality parchment and luxury bindings $-^{6}$, complex iconographical programmes appear in Middle Byzantine sacred books. Not only the most famous illustrated codices belong to this period -

\footnotetext{
${ }^{5}$ For a succint diachronic account of the evolution in the West, see SUSAN GILLINGHAM, Psalms through the Centuries. Oxford: OUP, 2008, pp. 56-66. At pp. 62-3, Gillingham notes that, paradoxically, the practice of illustrating Psalters in the West began at the same time as the iconoclast crisis.

${ }^{6}$ E. CRISCI, I più antichi manoscritti greci della Bibbia. Fattori materiali, bibliologici, grafici. In PaOlo CHERUBINI, editor, Forme e modelli della tradizione manoscritta della Bibbia. Vatican City, 2005, 1-31; GugLIELMO CAVAllo, Ricerche sulla maiuscola biblica. Florence, 1967; IRMGARD HUTTER, Marginalia decorata. In A. BRAVo GARCíA and I. PÉREz MARTín, editors, The Legacy of Bernard de Montfaucon: Three Hundred Years of Study on Greek Handwriting. Proceedings of the Seventh International Colloquium of Greek Palaeography (MadridSalamanca, 15-20 September 2008). Bibliologia 31. Turnhout: Brepols, 2010, 98-106, esp. p. 104 and pl. 10.
} 
notably, the Menologion of Basil $\mathrm{II}^{7}$ as well as the illustrated Metaphrastes manuscripts, ${ }^{8}$ the famous Marcian Cynegetica, ${ }^{9}$ the illuminated copies of Cosmas Indicopleustes, ${ }^{10}$ the moralized Physiologos, ${ }^{11}$ various illuminated Psalters, ${ }^{12}$ and perhaps most significantly, the very elaborately illustrated Octateuchs ${ }^{13}-$, but also, across each individual artist's variations, a new style emerges, variously defined as 'spiritual' or 'hieratic', exuding a self-assured rarefaction and beauty. ${ }^{14}$

The roots of this iconographical language are to be sought in the earlier illustrative programmes from the iconoclastic era, to which these newer productions selfconsciously hint, and upon which they are based. Therefore, beginning with the earlier period, we shall observe in what way imagery was used in sacred books; then, turning to the eleventh century, we will examine what transformations occur, and why. In both periods it would appear that a crisis in the status of images had repercussions for the

\footnotetext{
${ }^{7}$ The most recent study is a collection of essays accompanying a new facsimile edition of this precious codex: F. D'Aiuto and I. PÉrez MARTín, editors, El Menologio de Basilio II: Città del Vaticano, Biblioteca apostolica vaticana, Vat. gr. 1613: libro de estudios con ocasión de la edición facsímil. Vatican City/Athens/Madrid, 2008.

${ }^{8}$ NANCY SHEVCHENKo, Illustrated Manuscripts of the Metaphrastian Menologion. Chicago, PA, 1990.

${ }^{9}$ IohAnNIS SPATHARAKIS, The Illustrations of the Cynegetica in Venice: Codex Marcianus graecus Z 139. Leiden: Brill, 2004, sic, but really MS Marc. gr. Z 479.

${ }^{10}$ Maja Kомinкo, 'The World of Cosmas: the Universe Described and Depicted in Byzantine Manuscripts of the Christian Topography', unpublished DPhil, University of Oxford, 2006.

${ }^{11}$ M. Bernabò, G. Peers and R. TARAsconi, Il Fisiologo di Smirne. Le miniature del perduto codice B. 8 della Biblioteca della Scuola Evangelica di Smirne. Millennio medievale, 7. Florence: SISMEL, 1998.

${ }^{12}$ Christof Eggenberger, Das Psalterbild als Exegese. In Testo e immagine nell'alto medioevo, Settimane di Studi del Centro Italiano di Studi sull'Alto Medioevo 41, Spoleto, 1994, 773-98, 16 pl. My project at Ars edendi, Stockholm University, concerns the publication of one of these Psalters, Vaticanus graecus 752, a Constantinopolitan production datable around 1059, whose images relate to the catena commentary prepared ad hoc for this manuscript. The project is carried out in collaboration with Dr Glenn Peers, University of Austin, Texas.

${ }^{13}$ Kurt Weitzmann and Massimo Bernabò, The Byzantine Octateuchs. Princeton, NJ, 1999, have published the complete corpus, but see also the pioneering work by JOHN LOWDEN, The Octateuchs: a Study in Byzantine Manuscript Illustration. University Park, PA, 1992.

${ }^{14}$ See the recent judgement of OlGa Popova, The 1061 Gospel Miniatures (St. Petersburg, NLR, cod. Gr. 72) and Byzantine Art of the 1060s and 1070s. In 'E $\xi \varepsilon \mu \pi \lambda o v$. Studi in onore di Irmgard Hutter I (= Nea Rhome 6, 2009), 249-71.
} 
use of images in manuscripts. While the sharpness of the iconoclastic crisis largely explains the polemical edge to the ninth-century illustrations, the subtler and more insidious critique of image worship that threatens the Byzantine church at the beginning of the eleventh century requires a persistent, learned answer from the illustrative programmes that seek to affirm and proclaim Christian truth and values. Book illustration could claim the advantage of remaining immune from the criticism of icon worship, in so far as its role in personal prayer and meditation could at the very least vary, but the throngs of miniatures filling in the otherwise empty margins proclaim a status for the image, and confer on it official and irrevocable powers of communication. This massive presence implies clear choices in terms of the Christian self-definition, proclaiming that it simply could not work as a religion without figural representation.

\section{Manuscript Illustration against Iconoclasm}

If in general the period of Iconoclasm, as it is widely acknowledged, laid the groundwork for the Byzantine theory concerning images, ${ }^{15}$ the particular instances of book illumination at that time also laid the foundations for the future developments of this art form. In his article describing the revival of painting after Iconoclasm, Robin Cormack takes as his basic evidence nine works, of which five are important illuminated manuscripts extant from the ninth century: the Chludov Psalter, the Paris Gregory, the Walters Art Gallery New Testament, the Bible of Leo the Patrician, the Paris Psalter. Although each of these luxury illustrated books obviously presents a

\footnotetext{
${ }^{15}$ The bibliography on this period is truly vast. For an orientation, and a wider selection of references to those mentioned here, see LeSLIE BRUBAKER and JOHN HALDON, Byzantium in the Iconoclast Era (c. 680-850), the sources: an annotated survey. Birmingham Byzantine and Ottoman Monographs 7. Aldershot: Ashgate 2001, and now by the same authors Byzantium in the Iconoclast Era (c. 680-850), a history. Cambridge: CUP, 2011.
} 
separate set of issues, Cormack groups them in support of his thesis, "that after Iconoclasm the role of the patron in the creation of the painting was substantial, both in the choice of iconography but also in the way the artist visualized his subject matter". According to Cormack, though this role is not new, it can be retraced more precisely for the first time in these examples, which demonstrate that "the 'disposition' of art is the business of the church". ${ }^{16}$

The evidence for this high ecclesiastical patronage is provided, in the main, by the activity of Patriarch Photios (c. 810-c. 893), whose erudite exegesis has been convincingly related to the illustrative programme of the Paris Gregory ${ }^{17}$ and whose preaching at the inauguration of the first figural mosaic to be represented in Hagia Sophia, that of the Virgin and Child between Archangels, loudly proclaims the victory of the iconodules. ${ }^{18}$ Sansterre comments that Photios' pro-image statements in this famous homily of 867 were made "comme une déclaration de circonstance". ${ }^{19}$ According to Sansterre, Photios' involvement with illuminated books should not blind us to his real passion, that of reading texts. Sansterre structured his (very useful) article along the rift between the status of words and images often discussed in the sources, arraying them somewhat artificially either sides of this fence. If Photios sides with words, then his once-off over-the-top defense of images -however historically unique and massively influential- can be safely disposed of as a rhetorical exercise. But would

\footnotetext{
${ }^{16}$ RoBin CORMACK, Painting after Iconoclasm. In Iconoclasm, ANTHONY BRYER and JUdITH HeRRIN, editors, Birmingham: Centre for Byzantine Studies, 1977, 147-63, at p. 155.

${ }^{17}$ LESLIE BRUBAKER, Vision and Meaning in Ninth-Century Byzantium: Image as Exegesis in the Homilies of Gregory of Nazianzus. Cambridge: CUP, 1999.

${ }^{18}$ Photios, Homily XVII, English transl. by CYRIL MANGo, The Homilies of Patriarch Photios. Cambridge, MA, 1958, pp. 286-96.

${ }^{19}$ J.M. SANSTERRE, La parole, le texte, et l'image selon les auteurs byzantins des époques iconoclaste et posticonoclaste. In Testo e immagine nell'alto medioevo, Settimane di Studi del Centro Italiano di Studi sull'Alto Medioevo, 41. Spoleto, 1994, 197-240, at p. 231.
} 
Photios himself have drawn such a sharp distinction in quite this way? If Photios' elegant prose is open to interpretation, a quirkier piece of evidence ties down the high prelate to manuscript illustration in a way that is harder to shake off. In the Life of Ignatios by Niketas the Paphlagonian, a passage describes four precious books from Photios' library that were discovered by the imperial spies in 867 , confiscated and later burnt as punishment against the deposed patriarch. ${ }^{20}$ Mango's inclusion of the first part of this description in his English anthology of sources on Byzantine art has made the ekphrasis concerning the first tome widely known. ${ }^{21}$ The passage is in fact considered a key witness to the practice of manuscript illumination. ${ }^{22}$ The account describes the contents of the first tome, which contained the Acts of a supposedly false synod against Patriarch Ignatios (c. 797-877). There were seven Acts, each of which was headed by a picture of Ignatios in colour, with captions, painted by Gregory Asbestas, bishop of Syracuse, a partisan to Photios' cause.$^{23}$ According to this text, bishop Gregory

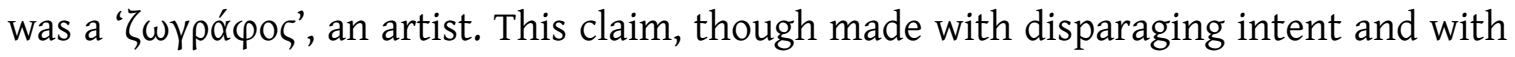
the underlying assumption that artists are a doubtful, if not an outright immoral,

\footnotetext{
${ }^{20} \mathrm{PG} 105,540-542$.

${ }^{21}$ CYRIL MANGo, The Art of the Byzantine Empire, 312-1453: Sources and Documents. Englewood Cliffs, NJ, 1972, pp. 190-2; see also idem, The Liquidation of Iconoclasm and the Patriarch Photios. In Iconoclasm, BRYER and HERRIN, editors, 133-40, at p. 140.

${ }^{22}$ Alexander Kazhdan and Henry Maguire, Byzantine Hagiographical Texts as Sources on Art. Dumbarton Oaks Papers, 45 1991, 1-22, at p. 20: "Probably the most significant information related to illuminated book production".

${ }^{23}$ Photios controversially chose Asbestas as the celebrant for his second consecration as patriarch in 877: on this figure, see PATRICIA KARLIN-HAYTER, Gregory of Syracuse, Ignatios and Photios. In Iconoclasm, BRYER and HERrin, editors, 141-5, esp. p. 144; and the remarks by CYRIL MANGO, The Liquidation of Iconoclasm, p. 140: "an amateur artist who drew uncomplimentary miniatures of Ignatios in the margins of a manuscript". The occasional nature of these drawings, which Mango seems to underline here, does not very well tally with the description of them as headpieces to the text, executed in colour.
} 
category, can probably be accepted at face value..$^{24}$ Its significance lies in the fact that images in manuscripts were directly, as well as indirectly, reflecting the intentions of the church hierarchy, and could be manipulated and controlled by ecclesiastical authorities just as much as texts, but with a more immediate effect, in turn amplified by ekphrasis. ${ }^{25}$ The Asbestas images of Ignatios in the luxury manuscript in Photios's possession are a case in point.

In a pithy, pointed remark in a footnote, Mango characteristically gives a key interpretative hint: "The miniatures described here were evidently a parody of a martyrdom cycle". The seven scenes depict a series of tortures and insults suffered by Ignatios, which, according to the captions, were fully deserved by the patriarch. This parody must have been intended by the hagiographer to work on two levels: one of overt and true condemnation, demonstrating the full wickedness of Photios and Asbestas in criticizing Ignatios; but also one of subverted, Christian piety, in which the Christian beholder identified Ignatios's sufferings with those of a victorious martyr. The captions associated with the seven images depicted by Asbestas play a key role in the accusations. Some designate Ignatios as 'The Devil', Simon Magus, and Antichrist, thus denouncing his role as a wicked and simoniacal bishop; but it has not yet been remarked that those referring to the third and fifth picture, 'ó viò $\tau \tilde{\eta} \varsigma$ $\alpha \dot{\pi} \omega \lambda \varepsilon \varepsilon^{\prime} \alpha \varsigma$ ' (the

\footnotetext{
${ }^{24}$ CORMACK, 'Painting after Iconoclasm', p. 160, compares Gregory to the near-legendary painter Lazaros, a monk who upheld with his painting the iconodule cause and was twice chosen as ambassador to Rome in 855 and 865. Corrigan also upholds the belief that "in speaking of the artists of the marginal psalters, [...] we are speaking of people who, like their intended audience, were members of the highest levels of Byzantine intellectual society" (KATHLEEN CORRIGAN, Visual Polemics in the Ninth-Century Byzantine Psalters. Cambridge: CUP, 1992, p. 7), and enumerates John the Grammarian among the artists themselves: see p. 6 and n. 21, with reference to Photios' Homily XV and S. GERO, John the Grammarian, the Last Iconoclastic Patriarch of Constantinople, the Man and the Legend. Byzantina, 3-4 1974-5, p. 25 n. 11.

${ }^{25}$ On the use of ekphrasis in Byzantine rhetoric, see L. JAMES and R. WEBB, "To understand ultimate things and enter secret places": Ekphrasis and Art in Byzantium. Art History, 14 1991, 1-17, with reference to Photios at p. 13.
} 


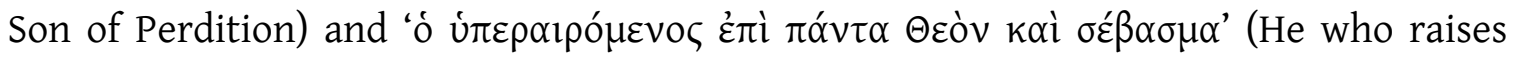
himself above God and above worship), combine in an allusion to 2 Thessalonians 3-4, a passage on the coming of the Antichrist. This passage refers to the proper worship, the 'sebasma', a word which recurs at Acts 17,23, the famous passage where Paul on the Areopagus asks the Athenians whom it is that they worship under the inscription 'To an unknown God'. Thus the accusation of iconoclasty is also piled up on Ignatius through these references.

To a Christian viewer, however, seeing the tortures of a martyr would have inspired pity and admiration, evoking the sequela Christi in the Via Crucis (esp. in the spitting and dragging described for the miniatures), while the captions would be seen as unjustly applied as was the inscription 'INRI' on Christ's Cross. In other words, the hagiographer plays between denouncing the horrors piled on his champion, Ignatios, in order to highlight Photios as a true devil in contriving this pseudo-martyr sequence, while at the same time avoids the risk of truly ridiculing Ignatios by appealing to the Christian sensitivity in looking at a martyr's cycle, where scorn, mockery and physical torture ${ }^{26}$ identify the sufferer with Christ and complete his sanctification. It is for this double potential that the hagiographer -I suggest- develops the ekphrasis and can keep in his narrative what was effectively an indictment of Ignatios as iconoclast and simoniacal bishop.

The second part of this passage, not being available in Mango's translation, is less wellknown. It describes the second precious book found in Photios' possession, which may not have contained pictures, as we have no mention and no ekphrasis of them. This

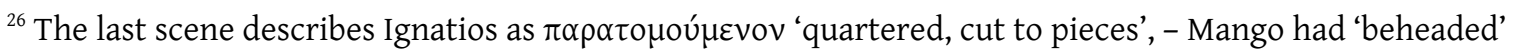
with a question mark; cf. LSJ: $\pi \alpha \rho \alpha \tau o \mu \eta \dot{~=~ r e b a t e ~ c u t ~ i n ~ a ~ r o c k ; ~ I I: ~ s e c t i o n ~ o f ~ a ~ s e t t l e m e n t, ~ q u a r t e r, ~ d i s t r i c t . ~}$ Thus probably 'quartered' rather than 'beheaded'. See also $\pi \alpha \rho \alpha \tau \varepsilon$ ' $\mu \nu \omega=$ cut to pieces (usually of animals); also cut, wound, maim; slaughtered, sacrificed (LSJ).
} 
book was a luxury copy of a text against Pope Nicholas I (c. 800-867), who had supported Ignatios. Furthermore, a second copy of both these books was found in Photios' unsuccessfully absconded book bags. ${ }^{27}$ These extra copies had been produced for King Louis II of France (846-879), and were to be sent to the king together with other gifts in an embassy to enlist French help in overthrowing the pope from his see. All four books were seized by the Byzantine emperor, and, after being exposed to the public so that all could witness to Photios' wickedness, were burnt by order of the synod in front of their author. In the narrative of Ignatios' hagiographer, Photios' precious books and their controversial, polemical images illustrate the power of these objects as official manifestos for internal and international politics, and their fate at the stake equally implies the seriousness with which these means of communication were perceived.

Asbestas' famous caricatures of Ignatios have been compared to the almost cartoon-like lampooning of the heresy of iconoclasm in the Chludov Psalter for both themes ${ }^{28}$ and style. ${ }^{29}$ As Anastasios of Sinai maintained, in times of doctrinal polemics, images, not

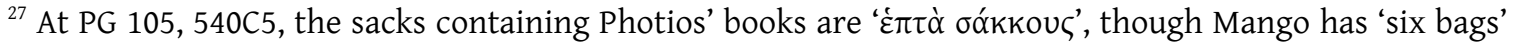
in his translation. At PG 105, 541 C1-2, the transition between the Book with the Acts and the next is introduced by the words 'one... the other' in the singular ( $\left.\dot{\eta} \mu i^{\alpha} \alpha . . . \dot{\eta} \dot{\varepsilon} \tau \dot{\varepsilon} \rho \alpha\right)$, while in conclusion (C13-14) we learn that of each book there were two copies, one made to be sent, the other to be kept by Photios, so

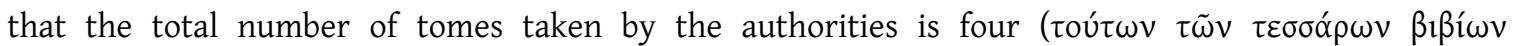
$\delta \rho \alpha \xi \alpha \dot{\alpha} \mu \varepsilon v o \zeta$ o $\beta \alpha \sigma \iota \lambda \varepsilon u ́ \varsigma, \ldots)$. A critical edition of this important text is not yet forthcoming.

${ }^{28}$ KAZHDAN and MAguiRE, Byzantine Hagiographical Texts, p. 20 and n. 186: "In his paintings Gregory Asbestas compared Ignatios to the devil and to Simon the Sorcerer, just as in the Psalter there are miniatures and legends identifying the Iconoclasts with these characters".

${ }^{29}$ See, inter alia, CORMACK, 'Painting after Iconoclasm', at p. 160: "This abusive but inventive cycle may have been in the manner of the Chludov Psalter". See also CoRRIGAN, Visual Polemics, pp. 6-7.
} 
texts, can convey the truth without fear of their being altered and distorted. ${ }^{30}$ The Chludov Psalter, the earliest illustrated Psalter in Byzantium according to the extant evidence, attests that the Byzantines appreciated and practiced this form of pictorial record in polemical times. The images containing a direct indictment of iconoclast bishops as simoniacal and as Christ-offenders are enshrined in the eloquent imagery of this Psalter. ${ }^{31} \mathrm{~A}$ two-tiered typology is operative in these illustrations, which provide first a New Testament reference for the Psalm verse, and then a contemporary reference in parallel to the biblical one. Thus, for example, on fol. $51 \mathrm{v},{ }^{32}$ he who "trusted in the abundance of his riches" (Ps. 51:9) has been punished in the same way as Simon Magus is punished, being trampled on by St Peter while spilling his gold; but a second visual reference is also inserted, so that just as St Peter, so the iconodule Patriarch Nikephoros (as the clipeate icon of Christ he holds firmly attests) is trampling over the iconoclast John the Grammarian, who spills his gold as a 'second Simon'. ${ }^{33}$ The corruption implied in the selling of ecclesiastical offices is here pointedly joined to the condemnation of iconoclasty, thus compounding the problems in what was to all intents and purposes an internal schism of the Byzantine Church.

The second image referring to iconoclasm in the Chludov Psalter works in the same twofold manner: at fol. $67 \mathrm{r},{ }^{34}$ the Psalm verse “...in my thirst, they gave me vinegar to

\footnotetext{
${ }^{30}$ K. PARRY, Depicting the Word: Byzantine Iconophile Thought of the Eighth and Ninth Centuries. Leiden: Brill, 1996, at p. 158, quoting a translation of PG 89, 196AD. See now the edition by KARL-HeInz UtHEMANN, Anastasius Sinaita, Viae Dux. Corpus Christianorum Series Graeca 8. Turnhout-Leuven: Brepols, 1981, I, 1 and XII, 1, pp. 8-9, 1l. 27-34 and pp. 201-02, 1l. 4-30. Further references in SANSTERRE, La parole, le texte et l'image, p. 207, n. 36 and p. 221.

${ }^{31}$ For a full discussion, see CoRRIGAN, Visual Polemics, ch. 2.

${ }^{32}$ CORRIGAN, Visual Polemics, fig. 39.

${ }^{33}$ The comparison finds a textual source in Patriarch Methodios (843-7), Canon on the Setting up of the Holy Images: see CORRIGAN, Visual Polemics, p. 2.

${ }^{34}$ CORRIGAN, Visual Polemics, fig. 42.
} 
drink" (Ps. 68:22) is read as a typological reference to the Crucifixion, depicting in the margin a Christ on the cross being offered a sponge with vinegar on a high stick. At the second level, the contemporary event is articulated in a precise iconography: two iconoclasts are holding a long pole at the end of which is a sponge that has been immersed in the cauldron below, which contains a mixture of whitewash. They are pointing the sponge at the clipeate image of Christ above them. Subtly, the parallel imagery also makes the point that the image of Christ really stands for (re-presents) Christ, and just as the historical Jesus was mocked by his contemporaries, so the iconoclasts' slighting of the image of Christ enacts a similar sin. One also wonders whether the specific placing of the icon high above the iconoclast's head-level, which requires the use of a long pole for its erasing, might contain a reference to the frequently debated question, at what height were devotional images acceptable. ${ }^{35}$

In commenting on this image, Corrigan draws out the implicit parallel between the Jews as Christ-slayers and the Iconoclasts, ${ }^{36}$ bringing to bear the literary background of Adversus Judaeos literature on a further layer of polemic contained in these images. Through her innovative approach to the ninth-century illustrated psalters, Corrigan explores inter-faith issues directed on the one hand to anti-Jewish polemic, and on the other to a reaction to the increasing 'threat of Islam', as chapter 5 is entitled. This broader milieu is instigated and justified by the causal connections between these monotheistic, but aniconic, religions and the wave of iconoclasm. ${ }^{37}$ However,

\footnotetext{
${ }^{35}$ PARRY, Depicting the Word, p. 50, referring to a passage by Theodore of Stoudios, PG 99, 353A. Images at a lower level would more easily be the object of undue (in the iconoclasts' eyes) devotional practices.

${ }^{36}$ On the intersection between this literature and the icons debate, see PARRY, Depicting the Word, 46-8.

${ }^{37}$ GotThARD STROHMAIER, Byzantinischer und jüdisch-islamischer Ikonoklasmus. In JOHANNES IRMSCHER, editor, Der Byzantinische Bilderstreit. Leipzig, 1980, 83-90. For a collection of stimulating essays taking a comparative approach to Byzantine and Muslim art, see ANTHONY CUTLER, Image Making in Byzantium,
} 
accusations may not be as sharply intended as Corrigan at times implies: given that the Psalms are set in Jewish times, it is natural that the Jewish characterization of the figures should appear as such in the images. It is noteworthy that the existence of Jewish art is defended not only in the recurrent depiction of the objects for temple worship commanded by God, but even at one point more specifically in the depiction and naming of the old Testament artist, Beseleel, who executed them. ${ }^{38}$ The old Testament basis for 'iconography' -in the sense of objects of cultic practice- is as necessary to the Christian iconodule as the further justification that Christ's incarnation enables the anthropomorphic representation of God, distinct from the fashioning of idols. Thus, the theme of the distinction between icon and idol provides a mainstream theme for this exegetical iconography, articulating the self-reflection on the proper place, forms and value of religious art for a religion that defines itself as the continuation of that described in the old Testament. ${ }^{39}$ Iconoclasm as a crisis point led to the adoption of images as a mark of identity. ${ }^{40}$

The evidence of illuminated manuscripts from ninth-century Constantinople strongly proclaims the iconodule victory and specifically supports the re-unification of word and image. Images are necessary co-carriers of the religious message, not only because

\footnotetext{
Sasanian Persia and the Early Muslim World. Images and Cultures. Farnham: Ashgate 2009, esp. VI, The Image of the Word in Byzantium and Islam: an Essay in Art-Historical Geodesy.

${ }^{38}$ CoRrigan, Visual Polemics, p. 34 and fig. 44, referring to the image in Pantokrator Psalter, fol. 165r, commenting Psalm 113. See also the article by Suzy DufRenNE, Une illustration "historique" inconnue du psautier du Mont-Athos, Pantokrator no. 61. Cahiers Archéologiques, 15 1965, 83-95, on which Corrigan's paragraph is based.

${ }^{39}$ The delicate balance between recognizing Jewish inheritance and avoiding Judaizing trends is a frequently debated issue; the Marcionite refusal of the old Testament is at all costs to be avoided: cf. Parry, Depicting the Word, pp. 160-1.

${ }^{40}$ On art as identity marker, see the interesting remarks by JefFrey Featherstone, Icons as Cultural Identity. In M. MARTIANI-REBER and J.M. SPIESER, editors, L'Aniconisme dans l'art religieux byzantin. Geneva, 14 October 2009, forthcoming.
} 
they are effective in translating the exegetical meaning into visual typology, but also because of their potential for actualizing that message for a contemporary audience. This further step is a necessary part of reading and re-reading the sacred text. In polemical times, only images are immune from tampering, whereas texts can be rewritten and thereby altered and falsified. Images can, indeed, be destroyed, but insofar as they are extant, cannot easily be distorted.

By impressing into imagery a poignant exegetical and intellectual content, ninthcentury high-powered iconodules answer the criticism of animistic idolatry before images by sidelining this issue. Rather, they foreground their function as carriers of meaning in relation to the sacred text, bringing representations of the divine into a different qualitative plane with respect to images for worship. To a large extent, they also highlight the catechetical value of the image that, drawing from a stock of tradition that marks the identity of a group, brings this forward into a dynamic communication with any viewer. ${ }^{41}$ The potential for this avenue of mediation with the divine, its many-sided advantages, its almost limitless scope for creativity, was successfully defended against the straight-jacketing control of the iconoclast elite. But while with Photios we witness a replacing of this imperial control with an ecclesiastically approved official line -his 'strong guiding hand', as Brubaker says- ${ }^{42}$, the production of elaborate iconographical programmes in manuscripts very probably stemming from a monastic milieu maintained a freer modality of expression besides a high intellectual content. Thus, the polemical use of imagery in the ninth-century marginal Psalters undercuts this move towards an official, 'approved' iconography,

\footnotetext{
${ }^{41}$ GÜNTER LANGE, Bild und Wort. Die katechetischen Funktionen des Bildes in der griechischen Theologie des sechsten bis neunten Jahrhunderts. Würzburg: Echter Verlag, 1969, remains the classical study.

${ }^{42}$ LesLie BRUBAKER, Politics, Patronage, and Art in Ninth-Century Byzantium: The "Homilies" of Gregory of Nazianzus in Paris (B. N. gr. 510). Dumbarton Oaks Papers, 39 1985, 1-13, at p. 11.
} 
reserving an independent and active role for book illustration that safe-guarded the essence of the iconodule victory.

\section{Manuscript illumination in the eleventh century}

The dynamic use of imagery in eleventh-century manuscripts demonstrates the effectiveness of this undercutting. Nearly two centuries after Iconoclasm, illustrations continue to be devised and developed according to a concepteur's plan, for the expression of a particular set of issues, a 'message', based on the text they accompany but also pointedly related to contemporary events. But the way in which these images work to articulate their message becomes far less direct than the plain references to iconoclasm that the daringly polemical Chludov (and associated mss) could make to their contemporary situation. On one hand, the tradition of exegetical imagery on which these eleventh-century productions are based was far more extensive and developed than before; and keeping in line with this tradition, in the manner of textual florilegia, was the acceptable form theologizing took at that time. On the other, the political instability of the eleventh century probably inspired even greater caution in the manner of articulation of any theological or ecclesiastical concepts. While the echo of the Greek/Latin disputations of 1054 has been perceived in some illustrations, the full scale of the reflection of the debates in the exceptional manuscript production of this period has as yet to be appreciated. ${ }^{43}$ In what sense, if any, were the illustrative programmes answering contemporary discussions concerning the use of icons in

\footnotetext{
${ }^{43} \mathrm{M}$. BACCI, Le rôle des images dans les polémiques religieuses entre l'Eglise grecque et l'Eglise latine (XIXIII siècles). Revue belge de philologie et d'histoire, 81 2003, 1023-49. I thank Alessandra Bucossi for this reference. See also B. CROSTINI, Riflessi del contrasto con l'Occidente nei manoscritti studiti miniati del dopo-scisma (1054). In F. D’AIUTO, E. RugGieRI et al., editors, Ortodossia e Eresia a Bisanzio (IX-XII s.). Atti della IX Giornata di Studi dell'Associazione Italiana di Studi Bizantini (AISB), Roma, 5-6 Dicembre 2008 [= Rivista di Studi Bizantini e Neoellenici, 47 2011], 265-84.
} 
worship? Was 'iconoclasm' in any form rife and coming to the fore once again?

The attention that Charles Barber has bestowed on the theory of the icon in eleventhcentury Byzantium draws out a fundamental contrast embodied in two important and contrasting personalities that marked the intellectual and ecclesiastical life of the capital: Symeon the New Theologian (949-1022) and Michael Psellos (1017/18-c. 1096). The style of Christianity advocated by Symeon was centred in the individual's mystical experience, a light perceived at the end of the individual's spiritual journey. Symeon's meditative path was abstracted from material aids; it ended in a totally subjective realization that could not be passed on as such. On the other hand, Psellos is understood through his writings concerning icons as a Neoplatonist philosopher who values the mediation of material objects, and particularly beautiful works of art, as opening a window onto the immaterial world. This experience is shared by the community and available to any of the faithful, regardless of their intellectual preparation, because it originates with God and is transmitted thorough grace. The clash of these views, with repercussions beyond the world of icons to the selfunderstanding of Christianity, marks in various and manifold ways the eleventh century.

By looking at three specific areas that are found articulated with special emphasis in the manuscript iconography of this period, we shall see how, using the echo of parallel themes from the ninth century as a foil, the argument in favour of images advances one step further the definition of Christian identity. These topics are: 1 . the cult of saints; 2 . the consideration of the Christian people -the laity- as the basis for Christian belief; 3 . the universal power of communication of the visual for inter-ecclesial and extraecclesiastical (international) debates. The eleventh-century context made each of these 
aspects once more paramount to Christianity's self-definition, the issues being not only relevant for debates within the Byzantine church and with Rome, but also with respect to the position of the Greek church vis-à-vis other faiths.

The cult of saints

The proper way in which to handle the cult of saints was a point of debate during iconoclasm. The ninth-century iconodule monk and leader, Theodore of Stoudios (759826), invokes the need for both Vita texts and images to contribute to the Christian understanding of saints. ${ }^{44}$ His insistence is interpreted as yet another iconodule battlehorse in reaction to the iconoclast blast, but again this is to dismiss as irrelevant what for Theodore is central. The intense hagiographical activity of the eleventh century compels us to re-examine his case.

The layout of the famous Menologion of Basil II springs to mind. It has been often noted that the page is equally divided between a pictorial representation of the saint, variously depicted as 'orant' or in the action of martyrdom, and the hieratic Perlschrift text, which literally adorns with words the other half of the page, being no less pleasing to the eye than the vividly coloured images on a gold background. This manuscript exemplifies Theodore's point precisely: ${ }^{45}$ not just words, but words and images together, carrying equal weight, are necessary to the Christian cult of saints. Why? On one hand, there is the argument, this time a true iconodule sophism, that ink pigments that form words on the page are as concrete as colour pigments forming pictures,

\footnotetext{
${ }^{44}$ SANSTERRE, La parole, le texte et l'image, p. 227 and n. 131, cites two Epistles by Theodore in support of this point: see the edition by G. FATouros, Theodori Studitae Epistulae, 2 vols. Berlin-New York, 1992, II, 171 and 737-8.

${ }^{45}$ This claim is not identical to saying that the Menologion was made in order to exemplify Theodore's view. However, between a purely technical explanation for this specific layout, and one that also envisages some further meaning, I would not light-heartedly disregard the latter.
} 
therefore words and images have the same, equally unassailable status. The Armenian treatise against Iconoclasm published by Der Nersessian makes this point, ${ }^{46}$ but the composite and slightly dubious nature of this text -in terms of its attribution and dating-allows us to forsake the evidence for an understanding of Theodore's point. By making the words in books as concrete as images, this treatise does not advance the case for images as much as undermines the proper understanding of the text of the Scriptures as inspired. On the other hand, the 'ethical theory of saints', as has been termed, ${ }^{47}$ is not necessarily what Theodore is up against. Saints are models, exempla, of virtuous behaviour, and if the images of martyrdom have been said to be more moving for the soul when seen in colour, ${ }^{48}$ it is not just the emotional response (or in an idiom more appropriate for the eleventh century, the 'affective piety') unleashed by the art that Theodore is concerned with. Clearly, as paradigms of behavioural imitation, narratives are just as powerful as pictures, and often more precise. These narratives were liturgically read out aloud, and these performances, often accompanied by processions or other services, made them accessible to a wide audience. While Pope Gregory the Great was defending church art on the basis of its wide appeal to the unlearned, one cannot use this argument automatically with respect to the representation of saints in essentially elitist books.

Theodore's point must rather be construed as an indication that the ethical theory of saints is insufficient for true Christian practice. As individuals with a moral story -or

\footnotetext{
${ }^{46}$ S. DeR NeRSESSIAN, Une apologie des images du septième siècle. Byzantion, 17 1944-5, 58-87. LANGe, Bild und Wort, 78-84, p. 79.

${ }^{47}$ Milton Anastos, The Ethical Theory of Images Formulated by the Iconoclasts in 752 and 815. Dumbarton Oaks Papers, 8 1954, 153-60, repr. in idem, Studies in Byzantine Intellectual History. London: Ashgate, 1979, XI. ${ }^{48}$ On the power of images to move, see SANSTERRE, La Parole, le texte et l'image, pp. 204, 217. See also the exploitation of images for medieval piety as discussed in R. W. SOUTHERN, The Making of the Middle Ages. New Haven: Yale University Press, 1953, pp. 231-40.
} 
often with an immoral story that is turned into salvation by God's grace- saints stand as (more or less familiar) paradigms, but as saints, with halos and inscriptions and icons, they stand in churches (and in manuscripts) as witnesses to the communion of saints; their destiny as immortals admitted to the presence and vision of God prefigures the Christian hope of eschatological salvation. That is why their living presence is an axiom, expressed in the narrative of their miracles, in the extraordinary power of their relics, and in the honour bestowed upon them through their iconography. As Parry explains, there is an intrinsic distinction between living and dead matter, yet dead saints are living matter through their iconic representations. ${ }^{49}$ So the saints that burst in and pervade the margins of the eleventh-century Psalters ${ }^{50}$ affirm a complex view of Christianity that sees in them a continuation of Revelation in history. It is significant that this memory could not, in any way, just be expressed in words, while the figural representations convey in their style and appearance the special status that one can try, in words, to explain, and that the highly formalized caption, 'hagios', sanctions and summarizes. Participation in the communion of saints, and a relationship to the saints' world, cannot be purely mental, aniconic. In this sense, representations of saints are always 'life-like', involving the human sphere with all its particularities and limitations. The believer's relationship to the saints hinges on the fundamental concept of familiarity, determining the parameters of the viewer exposed to sacred $a r t .{ }^{51} \mathrm{~A}$ good example of this interaction is provided by the festival of Saint Theodore the Footsoldier, that the eleventh-century poet John Mauropous (c. 1000-1070) celebrates

\footnotetext{
${ }^{49}$ K. PARRY, Theodore Studites and the Patriarch Nicephoros on Image Making as a Christian Imperative. Byzantion, 59 1989, 164-83, at pp. 172-3 and n. 55.

${ }^{50}$ L. MARIÈS, L'Irruption des saints dans l'illustration du psautier byzantin. Analecta Bollandiana, 68 1950, $153-62$.

${ }^{51}$ Lowden's concept of 'familiarity' depends on the parameters of this experience, which is in turn inserted in daily living. See above, p. XXX. CROSS REF
} 


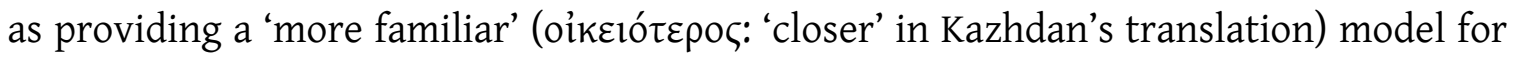
the participants to the festival than the icons of other 'Theodore' saints, 'mounted and brilliant and covered with gold, ${ }^{52}$ Thus the saint is posited as a model, but not an aloof one; he provides an immediate bridge between the domestic and the public spheres, as well as between the earthly and the divine. And this bridge is made accessible to the believer's experience through figural representation and devotional practice such as saints' festivals. In this sense, Christian ethics takes grace into account as much as works, while iconoclasts often support a view overwhelmingly in favour of the latter. But admitting grace is to admit ways in which the supernatural works its way into the natural world, and therefore allowing channels for such interactions through special objects -such as icons and relics- as well as established formulas, namely liturgical rituals.

Although Symeon's monastic spirituality is grounded in repentance, its unfolding is far from the normal requirements of the coenobium, but rather acutely abstract. As Barber explains it,

... Symeon was focused on the experience and vision of God. To incorporate icons in this economy presents some difficulties. An icon was only meant to pertain to ordinary human knowledge and visual capacity, while God must absolutely transcend these potential limits. Symeon might have chosen to use the medium of the icon to explore the changed nature of these capacities, yet he chooses not to do this. Rather, the experience of the divine, while made available in the present world, was not conveyed by or through the things in this world. Rather, as an intelligible experience this experience made itself available in an extraordinary manner as light. ${ }^{53}$

While this much is evinced from Symeon's own writings, the posthumous account of

\footnotetext{
${ }^{52}$ KAZHDAN and MAGUiRE, Byzantine Hagiographical Texts, at p. 13.

${ }^{53}$ CHARLeS BARBER, Contesting the Logic of Painting. Art and Understanding in Eleventh-Century Byzantium. Leiden/Boston, MA: Brill, 2007, p. 49.
} 
his Vita written by the Studite monk Niketas Stethatos around 1050 introduces in the narrative of Symeon's trial an icon of his spiritual father, Symeon Eulabes, as part of the cult he was promoting around him..$^{54}$ It may be significant that this icon comes into play only in the third and last part of the trial, and that the hagiographer goes to great lengths in showing Symeon's proper use of this object, including a prayer of petition, even though the overt role of the icon in the trial is to underwrite Symeon's mistake in promoting the cult of a sinful man -his spiritual father- and justify his exile on the part of the church authorities. These authorities order the removal of the title, 'hagios', from the panel, thus reducing the image from icon to portrait. This story has the double purpose of showing Symeon's orthodoxy with respect to icon worship, contrasting the heretical position he expresses in his own writings and reconducing his banishment within an acceptable realm of orthodoxy; but it also serves the purpose of affirming the power of the ecclesiastical authority over the proper use of icons and sanction of sainthood.

\section{The role of the laity}

That the rejection of the visual would have created a two-tiered Christianity, made of the elect and spiritual on the one side, and of the 'anthropomorphites' on the other, was another unacceptable consequence of the disposal of images according to Theodore of Stoudios. He stresses that the intellectuals and the unlearned both need instruction in the form of images, and the presence of images in books is the logical

\footnotetext{
${ }^{54}$ Vie de Syméon le Nouveau Théologien par Nikétas Stéthatos, I. HAUSHERR, editor. Rome: Orientalia Christiana 1928, pp. 121-22. Reference to this key episode is often found in the literature; see Nicolas OIKONOMIDES,

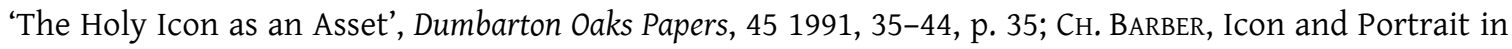
the Trial of Symeon the New Theologian. In ANTONY EASTMOND and Liz JAMES, editors, Icon and Word: the Power of Images in Byzantium. Studies Presented to Robin Cormack. Aldershot: Ashgate, 2003, pp. 25-34.
} 
corollary to this standpoint. ${ }^{55}$ Images are an immediate, expressive and necessary form of communication for men. Even to a scholar such as John Damascene, images provide a shortcut to the divine: either through lack of time, or through lack of willingness, John admits that images lead him to good thoughts more quickly and with less effort than reading a text. ${ }^{56}$

A fundamental aspect in the working out of Christian theology has been that of taking to heart the point of view of the laity, i.e. of the theologically uninitiated who, however, in their practice of Christian life and, more fundamentally, in their experience as believers, have cultivated a relationship to God as manifested through Christ in the Scriptures. In the eleventh century, an essential part of the debates concerning the Eucharist that were going on within the Latin world, notably with the protracted examination of Berengarius of Tour's doctrines on transubstantiation, tried to incorporate in the final statement of doctrinal approval centuries of devotion to the Eucharist in the practice of the faithful. ${ }^{57}$ While the high-flown theological arguments did in some case sound convincing, their flouting of popular belief was serious enough to require adjustment of the theory to the people's practice, not, as it were, in order to create a compromise, but because the experience of the faithful was considered key for the self-understanding of the church. That experience alone guaranteed an open channel between the worldly and the divine realms. As Barber correctly notes, the

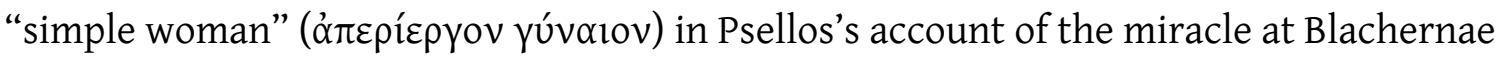
performs a key role in helping us to understand this investigation of spiritual

\footnotetext{
${ }^{55}$ SANSTERRE, 'La Parole, le texte et l'image', pp. 226-7 and the references there.

${ }^{56}$ Ibid., p. 211.

${ }^{57}$ Debates between the role of icons and the status of the eucharist are clearly at some level interconnected, and pursuing this link in the eleventh century should fruitfully highlight the theurgical aspect of iconography I am pursuing here in a limited fashion. See below, n. 71.
} 
seeing. She provides a model of inspiration, demonstrating that one can receive the miraculous sight despite one's performative incompetence. As such, she becomes the very guarantee for Psellos' understanding of the supernatural origin for the regular living visit of the Theotokos to the Blachernae.... ${ }^{58}$

In this respect, images as the medium by which theological subtleties are explained and offered in an immediately intelligible form became an important instrument not just to spread the catechetical knowledge of Scriptures, but more importantly to affirm the very concept of the need to keep everyone on board if the Church was to be truly catholic, i.e. universal. Nor was this elaboration, though in principle directed to all, and for all, in any way simplistic. The exegetical value of images and their complexity has often been underlined; straightforward typology was only the easiest interpretative tool available to the reader of these illuminated books by which to extract the meaning of the image placed next to the sacred text. Eleventh-century illuminators did not shy away from difficult representations, as in the striking example of the homily illustrated with the Magi adoring the polymorphous Christ as child, adult and old man, in MS Jerusalem, Taphou $14 .^{59}$ The introduction of the historiated initial, moreover, gave them scope for experimentation with different 'summaries' of the key images. Rather than the work of one 'concepteur' commanding, Photios-style, the iconographical vocabulary of any specific manuscript, the activity of a workshop planning and executing illuminated manuscripts, both conceptually and practically, can be envisaged, in the same way as a film studio produces films. The narrative ability goes

\footnotetext{
${ }^{58}$ BARBER, Logic of Painting, p. 98.

${ }^{59}$ See also Barber's interest in this image, Logic of Painting, pp. 92-3; to the literature cited there at n. 65 can be added G. KREALING McKay, Christ's Polymorphism in Jerusalem Taphou 14: An Examination of Text and Image. Apochrypha, 14 2001, 177-91; for the philosophical implications of this iconography, see E. JunoD, Polymorphie du Dieu-Sauveur. In K. Ries, editor, Gnosticisme et monde hellénistique. Louvain-laneuve, 1982, 38-46. Cf. also the reference in G. DAGRON, Holy Images and Likeness. Dumbarton Oaks Papers, 45 1991, 22-33, at p. 29 and n. 45.
} 
hand in hand with the ideas that want to be foregrounded in more symbolic ways, and technical expertise (including models) combined with creativity and the specific needs of each production. ${ }^{60}$

\section{Inter-ecclesial and international debates}

The potential of images to allude to church polemics has been seen in the overt ninthcentury images condemning iconoclasm. It can be argued that the rift between the positions of Symeon and Psellos as epitomizing contrasting views of Christianity had the potential of exploding into a schism within the Byzantine church, a potential that was handled in turn in repressive and in euphoric fashion, until the conflict escalated beyond the confines of the Greek church under patriarch Michael Keroularios (c. 10001059). It has been suggested that several images in eleventh-century manuscripts are devised as allusions to the 1054 debates, albeit in a covert way, and on this view the reflection of the debates on images is not only politically motivated, but also in part at least self-referential in upholding the value of images.

At the disputational level of pamphlets also, the question of icons re-surfaces ${ }^{61}$ This item was included in the 'list' of Latin errors among the Judaizing factors (including practices such as the use of unleavened bread) of which Latins are held guilty by the Byzantine hierarchy. As I have argued elsewhere, this continued presence of the iconoclast themes is not just a 'souvenir', as Der Nersessian defined it, of the iconoclast

\footnotetext{
${ }^{60}$ See for example my analysis of an unusual image from a Jewish apochryphon in the Theodore Psalter: http://www.arsedendi.org/wp-content/uploads//Toronto-paper-Crostini.pdf.

${ }^{61}$ Some aspects of these disputations have been described as being in a 'low poor taste' by E. CHRYsos, 1054: Schism?. In Cristianità d'Occidente e Cristianità d'Oriente (secoli VI-XI), Settimane di Studio del Centro di Studi Medievali di Spoleto 51, 2 vols. Spoleto, 2004, II, 547-71, at p. 561. For an overview of this type of literature, see TIA M. KolBABA, The Byzantine Lists: Errors of the Latins. Chicago: University of Illinois Press, 2000.
} 
controversy, although keeping memory of an event is of course the first, necessary step enabling the reading of its significance for contemporary matters..$^{62}$ Rather, allusions to iconoclasm may in fact essentially concern the relation between Constantinople and Rome, suggesting a parallel between the ninth-century situation and the contemporary one. While Humbert of Silva Candida (c. 1000-1061) appears to take issue, among other things, with the way of representing the Crucifix in Byzantium, Keroullarios absurdly complains that Latins do not venerate relics. Art appears to remain key to interecclesial debates.

Arethas of Caesarea compares the different ethnic representations of Christ to the different languages and alphabets in which the Gospels are written. ${ }^{63}$ Unlike language, images did not need translation. This non-verbal communication was directed crossculturally to address the debates with other religions. Contrast with Islamic aniconic (and just calligraphic) art was clearly one -negative- reason to develop Christian iconography. Distinctiveness from the "Other" was one of the issues; another was a need to manifest doctrinal differences in a concrete and public form. In this sense, aniconism became a polemical manifestation where the human form was a place of peace and reassurance for the Christian -and could perhaps be offered as a meetingpoint to the other faiths when there was a certain common ground, as for example with the figure of John the Baptist or the seven sleepers of Ephesus ${ }^{64}$.

\footnotetext{
${ }^{62}$ S. DeR NERSESSIAN, L'Illustration des Psautiers grecs du Moyen Age, II. Londres, Add. 19.352. Bibliothèque des Cahiers Archéologiques 5. Paris, 1970; cf. B. CROSTINI, Navigando per il Salterio: riflessioni intorno all'edizione elettronica del manoscritto Londra, British Library, Addit. 19.352. Prima parte. Bollettino della Badia greca di Grottaferrata, 55 2001, 191-215; Seconda parte. Il significato storico del Salterio di Teodoro, ibid., 56-7 2002-3, 133-209.

${ }^{63}$ ARETHAS, Pros eichonomachous, ed. WeSTERnIK, Scripta minora. Leipzig, 1968, pp. 79-80.

${ }^{64}$ On shared saints and pilgrimage sites, see Yousef MeRI, The Cult of Saints among Muslim and Jews in Medieval Syria. Oxford: OUP, 2002; on the cult of John, see NANCY KHALEK, Damascus after the Muslim Conquest: Text and Image in Early Islam. Oxford: OUP, 2011, ch. 3; Y. MOUBARAC, Le culte liturgique et
} 
With respect to the Jews, the choice of full-scale iconography was not, as we said before, seen purely in contrast to Jewish aniconic practice. Cassian, when advocating the absence of mental images from prayer, accuses of 'Jewish weakness' those who keep the thought of Jesus in the flesh while they pray..$^{65}$ In Cassian's sense, Jews remain tied to the world, and images are part of the immanent world that needs transcending in ascetic practice. In the catechetical effort to remind fellow Christians of the importance of the objects of Jewish worship, including, in the ark, the figural representations of the cherubs with human faces, the medieval Christians were aware of sharing the same commandments with the Jews, yet believed they were not contravening Mosaic law, but simply carrying forward these same (non idolatrous) liturgies with the addition of specifically Christian elements. Even the Synodikon of Orthodoxy proclaimed so, blessing those aware of the typological value of Old Testament symbols, while all the stories that accompanied its ritual proclamation had to do with Jews at last capable of realizing the true value of icons. ${ }^{66}$ Interest in the work of Cosmas Indicopleustes produced two very important illuminated manuscripts of this work in the eleventh century, witnessing to this theological position vis-à-vis Jewish cult. The extraordinary set of images combining Jewish cult objects with their Christian significance in the illustrated manuscript of the Physiologos translates the continuity suggested by the Synodikon into a striking visual form. ${ }^{67}$

populaire des VII Dormants martyrs d'Ephèse (ahl al-kahf): trait d'union Orient-Occident entre l'islam et la chrétienté d'après la documentation recueillie par Louis Massignon. Rome: Pontificia Università Gregoriana, 1961.

${ }^{65}$ PARRY, Depicting the Word, p. 5.

${ }^{66}$ BARBER, Logic of Painting, ch. 1, esp. pp. 17-18, with references to the key work by Jean Gouillard.

${ }^{67}$ E. REVEL-NeHER, Le Témoignage de l'absence: les objets du sanctuaire à Byzance et dans l'art Juif du XIe au XV siècle. Paris, 1998. 


\section{Conclusion}

While the 'purification' aimed at by the iconoclasts upheld a spiritualized religion devoid of its trappings, i.e. a religion without theurgy, non-figural or aniconic representation was accepted as able to appease the aesthetic sense and to provide apparently non-controversial decorative ornamentation that was deemed suitable to the sacrality of the place, or of the book. Like early Bibles, so Justinian's Hagia Sophia only displayed such aniconic art. ${ }^{68}$ In contrast to this, Theodore of Stoudios declares in a striking paradox that "unless there are images of Christ the incarnation might as well not have taken place; ... Had we denied the veneration of holy icons, our faith would have been empty, our message meaningless". This denial, he continues, would have ruined all good deeds, all virtue, all knowledge of the divine. ${ }^{69}$ In a similar vein, the patriarch Nikephoros, author of three Antirrhetica concerning the defense of icons, states that the circumscribability of Christ in icon-form is a necessary attribute of his being; if it failed, there would be no Christ, no Universe. ${ }^{70}$ The starkness of these pronouncements has again been taken as an exaggeration in reaction to the bitter and highly politicized iconoclast controversy that divided Byzantine Greek Christianity during the seventh and eighth centuries. However, it is thanks to this strong theoretical underpinning that the reprise, and arguably, the further development of

\footnotetext{
${ }^{68}$ L. BRUBAKER, Aniconic Decoration in the Christian World (6 $6^{\text {th }}-11^{\text {th }}$ cent.): East and West. In Cristianità d'Occidente e Cristianità d'Oriente (secoli VI-XI), Settimane di Studio del Centro di Studi Medievali di Spoleto 51, 2 vols. Spoleto, 2004, II, 573-89 and $10 \mathrm{pl}$.

${ }^{69}$ PG 99, 432D and PG 99, col. 173B; cited by KAZHDAN and MAGUIRE, 'Byzantine Hagiographical Texts', at p. 12.

${ }^{70}$ PG 100, 244CD; transl. pp. 85-6. A French translation has been recently published in the series Collection d'esthètique in Paris by Klincksieck, thereby giving this work a suitable place among the philosophical -and thus not merely theological- treatises on the subject of artistic representation, which this series intends to address in a cross-cultural and diachronic fashion: M.-J. MoNDZAIN-BAUDINET, Nicéphore: Discours contre les iconoclastes. Collection d'esthètique 52. Paris: Klincksieck, 1989.
} 
Christian iconography in the following centuries were made possible.

The variety and vitality of the iconography in expressing Christian identity and beliefs in the eleventh century can been understood as a fulfillment of Theodore of Stoudios's understanding of icons as an essential part of the Christian faith. Aspects of this faith, such as the cult of saints, and the need for unity in the Church, are particularly relevant to the eleventh-century context. At the same time the catechetical aspect of the image remains paramount. As a taught religion, Christianity can only be passed on through didactic aids such as pictorial cycles, enriching the Scriptures and their commentaries. If manuscript illumination cannot be directly related to popular catechetical aims, its declaration of the value of images for all holds up an unequivocal reminder of the necessity, for intellectual Christians, to remain aware of the contribution of all the faithful, whose perspective cannot be replaced by theological speculation alone.

At the end of his article 'Iconoclasm and the Monophysites', ${ }^{71}$ Sebastian Brock suggests that "the real -but unvoiced- issue underlying the whole Iconoclast controversy has nothing at all to do with Christology, and very little (directly at least) with the legitimacy of images. It is, rather, a question of how far the divine is allowed to impinge in the human world". Brock goes on to specify that "Iconoclasts wished to confine the sphere of divine 'interference' ... to certain given areas, ... the Eucharist and the saints", and supports this conclusion with a quotation from the (iconoclast) Horos of 754: "images/icons are ordinary matter, since no prayer of sanctification has been said over them". This raises the question of consecration as sealing the hallowing of a specific cultic object, thereby authorizing its use in worship and 'policing' its development. In

\footnotetext{
${ }^{71}$ SeBASTIAN Brock, Iconoclasm and the Monophysites. In BRYER and HeRrin, Iconoclasm, 53-57, p. 57. At n. 47, Brock quotes a similar definition by Brown, EHR 346 (1973), 1-34: "The iconoclast controversy was a debate on the position of the holy in Byzantine society".
} 
this sense, the eucharistic species which become at one point for the iconoclasts the only true image of Christ have the characteristic of doing so under a specific ritual and by a designated practitioner. ${ }^{72}$ As we have seen, questions of ecclesiastical control over images were less easy to handle and allowed for a wider range of interpretations. If the position of Symeon posed one kind of threat to the established hierarchy, Psellos' reasoning posed another type, unleashing the communicative power of images that was, in its essence, uncontrollable. ${ }^{73}$

Were the splendid images of eleventh-century manuscripts taken for devotional reading and admired in a form of rumination or, as Gillingham says, used for 'prayerful academic study'? Their aesthetic appeal was certainly part of their function, just as the musical enhancement of the Psalter by Pope Gregory the Great (c. 540-604) extended its use and universalized the involvement of all communities in its recitation down to this day. The visual impact and the tangible nature of these signs of the divine allows a leap to be made by the faithful that brings him -anagogically-from the sensitive to the supra-sensitive. The same activity of 'going beyond' is required in the reading of Scripture, especially of the Old Testament. ${ }^{74}$

The complexity of some of the iconographical programmes makes us think that there were indeed appreciative readers somewhere to be found, probably among the Byzantine elite, or perhaps abroad, where mss were sometimes sent as ambassadors for the Christian faith. I would contend therefore that the increase in the elaboration of pictorial cycles in the middle of the eleventh century was part of an attempt to keep

\footnotetext{
${ }^{72}$ See the very learned and balanced article on this topic by S. GERO, The Eucharistic Doctrine of the Byzantine Iconoclasts and Its Sources. Byzantinische Zeitschrift, 68 1975, 4-22.

${ }^{73}$ Averil CAMERon, The Anxiety of Images: Meanings and Material Objects. In A. Lymberopoulou, editor, Images of the Byzantine World. Visions, Messages and Meanings. Studies Presented to Leslie Brubaker. Aldershot: Ashgate, 2011, 47-56, p. 55.

${ }^{74} \mathrm{H}$. DE LuBAC, Exégèse médiévale: le quatre sens de l'Ecriture. Paris, 1959.
} 
the unity of the church despite its doctrinal controversies, and at once an attempt to counter and forestall such internal divisions as the resurgence of a type of iconoclasm had brought by affirming theurgy as an essential component for an undivided Christianity. In this sense, quite apart from philosophical doctrine, the medieval iconophiles can be said to be Neoplatonic. ${ }^{75}$

\footnotetext{
${ }^{75}$ PARRY, Depicting the Word, p. 21, objects to such a comparison.
} 